\title{
Effect of Nursing Intervention Guidelines for Women Undergoing Cesarean Section on the Occurrence of Postoperative Complication
}

Shadia Hassan; Mohamed Motawie; Sonia El-sharkawy; Nagat Shalaby*; Maha Ramadan Ali*

The Department of Maternal and Newborn Health Nursing, Faculty of Nursing, Cairo University, The Department of Obstetric and Gynecology, Faculty of Medicine, port said University; The department of pediatric, faculty of medicine, Suez Canal University; The Department of Maternity, Obstetric and Gynecological Nursing, Faculty of Nursing, Port said University*

\begin{abstract}
Background: Cesarean delivery is associated with increased maternal risks such as puerperal infection, hemorrhage, thromboembolism and death. Despite the gross increase in caesarean section rate, there is still high perinatal mortality.

Aim: The aim of the study was to determine the effect of nursing intervention guidelines for women undergoing cesarean section on the occurrence of postoperative complication.

Materials and Methods: The study was carried out in the obstetric and gynecological departments in Port Said Hospitals using a quasi-experimental study design. This study was carried out in the obstetric and gynecological department at three governmental hospitals located in Port Said city: Port Said general hospital, Port Fouad hospital and El-tadamon hospital. The sample constituted 250women; the study subjects were divided into two equal groups of 125 parturient women each, as follows: Group $A$; the study group, who receive postoperative care program. Group B; the control group who receive postoperative routine hospital care after cesarean section. Data were collected using four tools devised specifically for the study.

Results: Women in the study group had lesser percentages of danger signals that denote wound infection than the control group. Majority of women in the study group had mild pain grade in the third day after the operation compared to the control group. The overall incidence of wound complication was higher in the control group than the study group. There was a statistically significant difference between the study and control groups in favor of the former regarding; sub-involution of the uterus, secondary PPH, breast problems In addition to DVT, abdominal distention, constipation
\end{abstract}

Conclusion: The majority of women in the study group had mild pain grade in the third day after the operation compared to the control group. Incidence of wound complication was higher in the control group than the study group.

Key words: Cesarean section, Postoperative complication, Nursing intervention 


\section{Introduction}

THE intra-operative complications for elective and emergency CS are bleeding, lesion of the urinary bladder, urethra, intestines or arteries of the uterus. While the postoperative complications for elective and emergency cesarean section are bleeding, infection, anemia, increasing values of the blood pressure (140/100 or more), thrombosis, hematoma, high body temperature ( $38{ }^{\circ} \mathrm{C}$ and higher) as well as ileus (Elvidi-Gasparovic et al., 2006).

Concerning maternal complications, there is possibility of Intra-operative complications, which include; anesthetic complications: this is one of the major problems with emergency CS as deep venous clots that can travel to the lungs (pulmonary embolism) and brain (stroke). A full stomach is one of the most serious risk factors for general anesthesia because of the risk of inhalation of stomach content which is an extremely dangerous situation because the risk of patient's suffocation (Goer, et al., 2007).

In addition, General anesthesia may cause feeling sick, vomiting after surgery and sore throat if there is a tube in the airway. Spinals and epidurals anesthesia can lower the blood pressure and cause headache. Occasionally, they make the patients feel local tenderness in the back for a few days (Hoppe and Popham, 2007). Uterine lacerations are also more common at the lower uterine segment with a transverse uterine incision. These lacerations can extend laterally or inferiorly and can be repaired easily (Harish \& Sehdev, 2005).

Moreover, bladder injury is an infrequent complication; it is more common with transverse abdominal incisions and in repeated cesarean deliveries. Most commonly the bladder has been injured when entering the peritoneal cavity or when separating the bladder from the lower uterine segment. Operator experience and the emergency nature of the cesarean delivery were found to be risk factors for bladder injury during cesarean delivery (Rahman, et al., 2009). Injury to the ureter occurs in up to $0.1 \%$ of all cesarean deliveries and up to $0.5 \%$ of cesarean hysterectomies. It is most likely to occur when repairing extensive lacerations of the uterus (Harish\& Sehdev, 2005). Also bowel injury occurs in less than $0.1 \%$ of all cesarean deliveries. The most common risk factor for bowel injury at the time of cesarean delivery is adhesions from prior cesarean deliveries or prior bowel surgery (Phipps, et al., 2005).

Uterine atony is another intra-operative complication that can be occurred in a patient with a multiple gestation, polyhydramnios, failed attempt at a vaginal delivery in which the patient was on pitocin augmentation for a prolonged period is uterine atony (Harish \& Sehdev, 2005). In addition to excessive Blood Loss during a cesarean section which typically 
results from laceration of uterine vessels that occurs with extension of the uterine incision. Additional lacerations may extend into the vagina and result in significant bleeding and increased operative time. The risk of hemorrhage requiring blood transfusion increases substantially with increasing number of prior cesarean deliveries (Silver, 2006).

Concerning the Post-operative complications, Starr et al., (2005) mentioned postoperative complications of CS as wound infection; the risk of a wound infection ranges from $2.5 \%$ to higher than $15 \%$. There is a three-fold increased risk of puerperal febrile morbidity in women who had a CS, compared with women who had a vaginal delivery (Allen, 2003). US data showed that women who had cesarean birth were more likely to require readmission for uterine infection than women who had assisted or spontaneous vaginal birth, (Lydon, 2000). Australian women who had a caesarean birth were more likely to require readmission to hospital for undefined health problems in the first eight weeks after birth, compared to women who had unassisted vaginal births because physical complications, minor and major after caesarean section, may delay maternal recovery (Lobel, 2007).

Moreover, fascial dehiscence; occurs in approximately $5 \%$ of patients with a wound infection and suggested when excessive discharge from the wound is present. Urinary tract infection (UTI) is one of the most common causes for post cesarean febrile morbidity its incidence ranges from $2-16 \%$ and the process of placing an indwelling catheter for the surgery is a risk factor in itself (Liu et al., 2007) .

Pelvic thrombophlebitis is another infection - related to CS complication. Two percent of patients with an endomyometritis or wound infection can develop these complications. Moreover, slow return of bowel function may also occur during the postoperative period because postoperative narcotics may delay return of normal bowel function in a few patients. Thromboembolic complications; pulmonary embolism remains the leading direct cause of maternal death. The incidence of such complications can be reduced by the identification of high risk women and appropriate administration of thromboprophylactic measures (Bonney \& Myers, 2011).

\section{Aim of the study:}

The aim of this study was to; determine the effect of nursing intervention for women undergoing CS on the occurrence of health problem complications. 


\section{Materials and Methods}

Study Design: A quasi-experimental study design was used to determine the effect of nursing intervention for women underwent CS on the occurrence of postoperative complications. This could enrich obstetrics and gynecological body of knowledge with evidence based practice to reduce postoperative problems.

Sample: The subjects of the study were all parturient women who undergoing cesarean section and attending the obstetric and gynecologic departments in Port Said Hospitals at Port Said general Hospital, Port Fouad Hospital and El-Tadamon Hospital (The total sample size was 250 women).

Setting: Study was carried out in the inpatient (obstetric and gynecological department) at three hospitals located in Port Said city as: 1- Port Said general hospital is the largest public hospital affiliated by ministry of the wide range of maternity services; it has tree rooms and ten beds. Also, contain fifty-six physicians, eleven nurses and three workers. 2- Port fouad hospital at private and inpatient (obstetric and gynecological department) has four rooms each room has 4 beds, privet ward consist of four rooms. The services are running by fifteen physicians, ten nurses and two work aids. And 3- El-tadamon hospital at private and inpatient (obstetric and gynecological department) it has ten rooms at thirty three beds. The services are running by four physicians, nine nurses and three work aids.

\section{Data collection tools:}

Tool (1): Structured interviewing questionnaire for mother

Tool (2): A follow up observation sheet: It was used for mothers in both groups. It consisted of two parts: - The first part: - Postoperative physical care: This was used to record postoperative physical care given to the mother by the researcher in the study group immediately within two hours after the operation, three days, and after two weeks, it covered the following items as positioning, checking of vital signs, recording intake and output, care of catheter, and to record postoperative physical care given to the mother by the hospital in the control group.

The second part: - Performance of women: - This was necessary to record women's practice during the postoperative period, concerning initiation of breast feeding, body cleanliness and mobilization

Tool (3): Observation Checklist: - was constructed by the researcher to record postoperative women health problems in both groups. Such as after pain, wound pain, chest complications, urinary tract infection, healing of wound, and any minor or major problems after two to four hours, three days and after two weeks. 


\section{Content Validity:}

The researcher designed an opinnionnaire sheet to test the content validity of the assessment questionnaire sheet for nurses and mothers by a jury including 10 Experts in the field of obstetric and gynecology from medical and nursing faculty staff. It involved two parts:

A- The opinions of the experts for each item were recorded on a two-point scale: relevant, not relevant and clear, not clear.

B- General or overall opinion about the form, they were requested to express their opinions and comments on the tool and provide any suggestions for any additional or omissions of items. Then necessary modifications were done. This phase was carried out in a period of two months.

A pilot study, which was carried out on $10 \%$ from nurses. The main purpose of the pilot study were to test the clarity, feasibility of the tools and whether it was understandable, and to determine the time needed to fill the tool. The tool was handed to participants to fill it and collected by researcher. The time for the completion of the questionnaire sheet was ranged from 1- 1.30 hour. Following this pilot study, the process of data collection and implementation of educational program consumed 12 months from June 2010 to March 2011.

The investigator attended the inpatient unit from 2, $00 \mathrm{pm}$ till 9, 00 PM. four times per week; $1^{\text {st }}$ day and $2^{\text {nd }}$ day for study group, $3^{\text {rd }}$ day and $4^{\text {th }}$ day for control group. This was repeated until the sample size reached 250 women. Interviewing was carried out for each subject in the two groups (study group and control group, upon admission to the inpatient unit. The investigator introduced her to the mothers and explains the aim of the study in a simple way before teaching. The researcher started the interview, which lasted about 20 minutes. The study was carried out during the period from February 2011 to April 2012.

Mothers were followed -up by the researcher daily until discharge to observe maternal problems, which may arise during hospitalization. The mothers were interviewed again after discharge on the third day. During the follow - up visit observation, by means of the checklist, which was performed for each mother three times during the two to four hours after cesarean section on the third day and after two weeks, it was conducted at home. 


\section{Results}

Table (1): presents the utilization of ANC services among women in the two groups. It indicates that women in the study group had more mean number of antenatal visits $(9.5 \pm 1.8)$ than the control group (8.1 \pm 1.7$)$. Moreover, women in the two groups had partially similar proportion of minor problems during their last pregnancy. From Continuous vomiting constitute the higher percentage in the two groups.

The mode of last delivery was shown in table (2). The majority of women in both the study and control groups had CS (80.5\% and $84.5 \%$ respectively). Moreover, more women in the control group (63.3\%) had history of complications during the previous labor compared to $44.2 \%$ in the study group, this were mainly obstructed labor and premature rupture of membranes.

Table (3) Points to a statistically significant difference between the study and control groups regarding the level of the fundus during the third day after the operation $\left(\mathrm{P}=0.031^{*}\right)$. Thus more women in the study group had reached the normal level of the uterus (98.4\%) compared to those in the control group (92.8\%). While, the blood loss was partially similar in both groups with no statistical significant difference

Table (4) shows that the majority of women in the study group had started early the intake of oral fluids, in the first day after the operation compared to the control group (84.8\% vs. 5.6\% respectively), with a highly significant difference $(\mathrm{P}<0.0001 *)$. Moreover, they were less likely to suffer from vomiting or being exposed to difficult elimination. Also differences observed are statistically significant $((\mathrm{P}<0.0001 *)$.

Table (5) that woman in the study group had lesser percentages of danger signals that denote wound infection than the control group. Thus they showed lesser redness, edema, inadequate healing during the follow up care than the study group. Differences observed are statistically significant $((\mathrm{P}<0.0001 *)$.

Table (6) demonstrates that the great majority of women in the study group had mild pain grade in the third day after the operation compared to the control group (92.0\% vs. $4.0 \%$ respectively) with a statistical significant difference $\left(\left(\mathrm{P}<0.0001^{*}\right)\right.$. 
Table (7) compares the problems encountered among women underwent CS in both the study and control groups during the follow up schedule. It indicates that the overall incidence of retention of urine was higher (1.6\%) in the control group than the study group $(0.0 \%)$ with a highly significant difference $(\mathrm{P}=0.49)$ in the first day. Again, in the third day there was a statistically significant difference $(\mathrm{P}=0.49)$ between the control and study groups in favor of the former regarding; sub-involution of the uterus (1.8vs.0.0), vaginal bleeding (4.0vs.7.2), breast problems (12.8\% vs4.8\%). In addition to DVT (4.8 \%vs. $0.0 \%)$, abdominal distention, constipation (47.2 vs. 22.4) and hemorrhoids. Differences observed are statistically significant $((\mathrm{P}<0.0001 *)$.

\section{Discussion}

The past obstetric history in the present study revealed that the mean parity ranged between one and two Para among the studied sample. Li et al., (2003) reported that in New Jersy and Joseph et al., (2005) in Canada reported high rates of C.S in their studies among the nulliparous women. However, Abd El-hamid (2007) and Mahmoud (2007) found that more than two thirds of women who underwent C.S were multigravida and multipara and the small proportion of them was Primipara. Such a discrepancy between the above results may be explained by the differences in sample size and its criteria. Also, it could be due to the fact that the highest percentage of CS in the current study was of the primary type.

Concerning the current CS indications, the present study finding has indicated that previous CS was at the top of the list, with the highest percentage of indications. This was followed by mal-presentation and cephalopelvic disproportion. This is supported by ElRefaey, (2000) who stated that the majority of women had one or two previous deliveries and a sizable proportion of them had previous cesarean section. Meanwhile, McAleese (2000) has reported that previous CS is a relative indication of cesarean section. In addition, Hewson et al., (2000) have mentioned that planned CS is better than planned vaginal birth for the term fetus in the breech presentation. Also McAleese (2000) has stressed that cephalopelvic disproportion is an absolute indication for cesarean birth. Additionally, Chhabra et al., (2000) has reported that CS is the best treatment for a brow presentation with the head at the level of pelvic brim. These findings are going on with the present study. 
The better uterine contraction, with normal fundal level and lochia were noticed in the study group than the control group, with a significant difference between the two groups in favor of the former, this might be due to early mobilization and the practice of pelvic floor exercises. In addition, Robertson (2011) confirmed the association between the condition of the uterus during the postoperative period and the incidence of postpartum hemorrhage and puerperal infection.

Meanwhile, the present study has revealed statistically significant relation between the occurrence of moderate and severe level of pain and nursing care provided which was in favor of the study group $\left(\mathrm{p}=0.0001^{*}\right)$. Where the researcher used different measures for woman in the study group to alleviate pain such as; analgesic administration, relaxation exercises, therapeutic communication, measures to promote comfort and satisfaction as well as decreasing fear, tension and anxiety. In this respect William (2005) emphasized the importance of investigating the various factors associated with pain which are mainly; medical, technical and psychological factors. Similarly, Gilbert (2007) examined the postoperative pain after CS and found that postoperative pain is usually underestimated although it could be easily alleviated by EB pain relief measures. These were also used by the researcher for the study group.

Moreover, Abd El-Ati (2005) has reported that statistically significant difference among the two studied groups regarding constipation, breast engorgement, cracked nipple, and urinary tract infection. These findings were also in accordance with, yaagoub (2010) who found that wound infection and hemorrhages are the most frequent complications that happened after cesarean section.

Women who had delivered by C.S are at risk for developing minor problems that may be a sign for major problem that if not diagnosed as early as possible, may have a devastating effects on the mother so the early investigation and detection of these problems help in saving the mother's life. Eugene (2008), examined mothers reports of their postpartum experiences with pain stratified by method of delivery and pointed that about $79 \%$ of mothers who had a C.S experience pain from their surgery in the first 2 months after birth. 


\section{Conclusion:}

\section{Based on study findings, it can be concluded that:}

statistically significant improvement immediately in the practice of mothers as well as decreasing the incidence of health problems in the post-operative period. And statistically significant improvement knowledge of the mothers undergoing cesarean section regarding the different aspects of their post-operative care and care of their child and breast-feeding.

Recommendations:

Mother classes could be conducted in antenatal settings, outpatient clinics, to discuss the care that should be provided to women undergoing CS and possible complications. Further researches is needed in different settings to develop evidence based practice that focuses on issues related to postpartum maternal health problems either for women who delivered normally or by C.S. 


\section{References}

Abd El-Ati, E. (2005). Effect of Supportive Self-Care on Health Problems for Women Undergoing Cesarean Delivery. Doctorate Thesis, Department of Obstet. \& Gynecol., Faculty of nursing, Suez Canal University.

Abd-El Hamid, A. (2004). Postoperative complications following cesarean delivery in Zagazig: prevalence and nursing implications. Doctorate Thesis, Department of Obstet. \& Gynecol., Faculty of nursing, Zagazig University: P4.

Declercq, E.R, Sakala C. \& Corry, M.P. (2006a). Listening to mothers II: The second national U.S. survey of women's childbearing experiences. Am J Obstet. Gynecol.; 75 (1): 89-111.

Yaaqoub, N.K., (2010): Department Of Gynecology And Obstetric, Faculty of Medicine, University of Tikrit P.O. Box 42, Tikrit, Salahudin, Iraq .

Allen, V., O’Connell, C. Liston, R. \& Baskett, T. (2003). Maternal Morbidity Associated With Cesarean Delivery Without Labor Compared With Spontaneous Onset Of Labor At Term. Obstetrics \& Gynecology, 102:477-482.

Bonney, E.A. \& Myers, J.E. (2011). Caesarean section techniques and complications. Obstetrics, Gynaecology \&Reproductive Medicine; 21(4): 97-102. Available at: http://www.sciencedirect.com.zdl.zu.edu.eg. Accessed at April, 5, 2011

Chahabra, S., Bhagwat, N., \& Chakravorty, A. (2002). Reduction in the occurrence of Uterine Rupture in Central India. Journal of Obst and Gyne; 22(17): 39-42.

El - Refaey, A. ( 2000 ). The Effect of Pre And Post Operative Nursing Care For Woman Undergoing Elective Cesarean Section on Their Postoperative Health Condition . Doctorate Thesis, Department of Obstet. \& Gynecol., Faculty of nursing, Alexandria University.

Goer, H., Sagady, Leslie, M., \& Romano, A. (2007). Step 6: Does Not Routinely Employ Practices, Procedures Unsupported By Scientific Evidence. J. Perinat EDUC 16 (1), 32S - 64.

Liu, S., Liston, R.M, Joseph, K.S et al., (2007). Maternal mortality and severe morbidity associated with low-risk planned caesarean delivery versus planned vaginal delivery at term. Canadian Medical Association Journal; 176 (4): 455-60.

Lobel, M., Deluca R., (2007). Psychosocial Sequelae of Cesarean Delivery: Review and Analysis of Their Causes and Implications. Social Science \& Medicine, 64:P.p. 2272-2284.

Rahman, M.S, Gasem T, Al Suleiman SA et al., (2009). Bladder injuries during cesarean section in a University Hospital: a 25-year review. Arch Gynecol Obstet.; 279:349-352. 
Table (1):- History of previous labor of women in the study and control groups

\begin{tabular}{|c|c|c|c|c|c|}
\hline \multirow{3}{*}{ History of previous labor } & \multicolumn{4}{|c|}{ Group } & \multirow{3}{*}{ Significance } \\
\hline & \multicolumn{2}{|c|}{$\begin{array}{c}\text { Study } \\
(\mathrm{n}=77)\end{array}$} & \multicolumn{2}{|c|}{$\begin{array}{c}\text { Control } \\
(n=90)\end{array}$} & \\
\hline & No & $\%$ & No & $\%$ & \\
\hline $\begin{array}{l}\text { Type of last delivery } \\
\text { Vaginal } \\
\text { Assisted } \\
\text { Cesarean section }\end{array}$ & $\begin{array}{c}15 \\
0 \\
62 \\
\end{array}$ & $\begin{array}{c}19.5 \\
0.0 \\
80.5 \\
\end{array}$ & $\begin{array}{c}13 \\
1 \\
76 \\
\end{array}$ & $\begin{array}{c}14.4 \\
1.1 \\
84.4 \\
\end{array}$ & ${ }^{\mathrm{MC}} \mathrm{P}=0.458$ \\
\hline $\begin{array}{l}\text { Place of delivery } \\
\text { Hospital } \\
\text { Private clinic }\end{array}$ & $\begin{array}{l}60 \\
17 \\
\end{array}$ & $\begin{array}{l}77.9 \\
22.1 \\
\end{array}$ & $\begin{array}{c}81 \\
9 \\
\end{array}$ & $\begin{array}{l}90.0 \\
10.0\end{array}$ & $\begin{array}{c}\mathrm{X}^{2}=4.61 \\
\mathrm{P}=0.032 *\end{array}$ \\
\hline $\begin{array}{l}\text { Occurrence of complications } \\
\text { Yes } \\
\text { No }\end{array}$ & $\begin{array}{l}34 \\
43 \\
\end{array}$ & $\begin{array}{l}44.2 \\
55.8\end{array}$ & $\begin{array}{l}57 \\
33\end{array}$ & $\begin{array}{l}63.3 \\
36.7\end{array}$ & $\begin{array}{c}\mathrm{X}^{2}=6.15 \\
\mathrm{P}=0.013 *\end{array}$ \\
\hline $\begin{array}{l}\text { Type of complications } \\
\text { Obstructed labor } \\
\text { Premature rupture of membrane } \\
\text { Antenatal hemorrhage } \\
\text { Septicemia } \\
\text { Perineal tear } \\
\text { Stillbirth }\end{array}$ & $\begin{array}{c}{[\mathrm{n}=34]} \\
8 \\
23 \\
1 \\
1 \\
1 \\
0\end{array}$ & $\begin{array}{l}23.5 \\
67.6 \\
2.9 \\
2.9 \\
2.9 \\
0.0\end{array}$ & $\begin{array}{c}{[\mathrm{n}=57]} \\
25 \\
22 \\
2 \\
2 \\
1 \\
5\end{array}$ & $\begin{array}{c}43.9 \\
38.6 \\
3.5 \\
3.5 \\
1.8 \\
8.8\end{array}$ & ${ }^{\mathrm{MC}} \mathrm{P}=0.08$ \\
\hline
\end{tabular}


Table (2): Characteristics of current pregnancy of women in the study and control Groups

\begin{tabular}{|c|c|c|c|c|c|}
\hline \multirow{2}{*}{ Current pregnancy } & \multicolumn{4}{|c|}{ Group } & \multirow{3}{*}{ Significance } \\
\hline & \multicolumn{2}{|c|}{ Study } & \multicolumn{2}{|c|}{ Control } & \\
\hline Antenatal care visits & No & $\%$ & No & $\%$ & \\
\hline $\begin{array}{l}\text { No } \\
\text { Yes }\end{array}$ & $\begin{array}{c}0 \\
125\end{array}$ & $\begin{array}{c}0.0 \\
100.0\end{array}$ & $\begin{array}{l}15 \\
110\end{array}$ & $\begin{array}{l}12.0 \\
88.0\end{array}$ & $\begin{array}{l}\chi^{2}=15.957 \\
\mathrm{P}<0.0001 *\end{array}$ \\
\hline $\begin{array}{l}\text { Start of ANC visits } \\
\text { First trimester } \\
\text { Second trimester } \\
\text { Third trimester }\end{array}$ & $\begin{array}{c}91 \\
29 \\
5 \\
\end{array}$ & $\begin{array}{c}72.8 \\
23.2 \\
4.0 \\
\end{array}$ & $\begin{array}{c}44 \\
61 \\
5 \\
\end{array}$ & $\begin{array}{c}35.2 \\
48.8 \\
4.0 \\
\end{array}$ & ${ }^{\mathrm{MC}} \mathrm{P}<0.0001 *$ \\
\hline $\begin{array}{l}\text { Total number of ANC visits } \\
\text { Mean } \pm \text { SD }\end{array}$ & \multicolumn{2}{|c|}{$9.5 \pm 1.8$} & \multicolumn{2}{|c|}{$8.1 \pm 1.7$} & $\begin{array}{c}\mathrm{Z}=6.825 \\
\mathrm{P}<0.0001 *\end{array}$ \\
\hline $\begin{array}{l}\text { Occurrence of complications } \\
\text { Yes } \\
\text { No }\end{array}$ & $\begin{array}{l}87 \\
38 \\
\end{array}$ & $\begin{array}{l}69.6 \\
30.4\end{array}$ & $\begin{array}{l}91 \\
34\end{array}$ & $\begin{array}{l}72.8 \\
27.2\end{array}$ & $\begin{array}{l}\chi^{2}=0.312 \\
\mathrm{P}=0.576\end{array}$ \\
\hline $\begin{array}{l}\text { Type of complications } \\
\text { Continuous vomiting } \\
\text { Bleeding }\end{array}$ & $\begin{array}{c}{[\mathrm{n}=87]} \\
44 \\
2\end{array}$ & $\begin{array}{c}50.6 \\
2.3\end{array}$ & $\begin{array}{c}{[\mathrm{n}=91]} \\
53 \\
6\end{array}$ & $\begin{array}{c}58.2 \\
6.6\end{array}$ & \\
\hline Gestational Diabetes & 0 & 0.0 & 1 & 1.1 & ${ }^{\mathrm{MC}} \mathrm{P}=0.206$ \\
\hline $\begin{array}{l}\text { Toxemia } \\
\text { Twin pregnancy }\end{array}$ & $\begin{array}{l}1 \\
4\end{array}$ & $\begin{array}{l}1.1 \\
4.6\end{array}$ & $\begin{array}{l}1 \\
2\end{array}$ & $\begin{array}{l}1.1 \\
2.2\end{array}$ & $r=0.200$ \\
\hline $\begin{array}{l}\text { Increase liquor } \\
\text { Mal-presentation }\end{array}$ & $\begin{array}{c}0 \\
36\end{array}$ & $\begin{array}{c}0.0 \\
41.4\end{array}$ & $\begin{array}{c}2 \\
26\end{array}$ & $\begin{array}{c}2.2 \\
28.6\end{array}$ & \\
\hline
\end{tabular}


Table (3): Examinations of post cesarean section women in the study and control groups

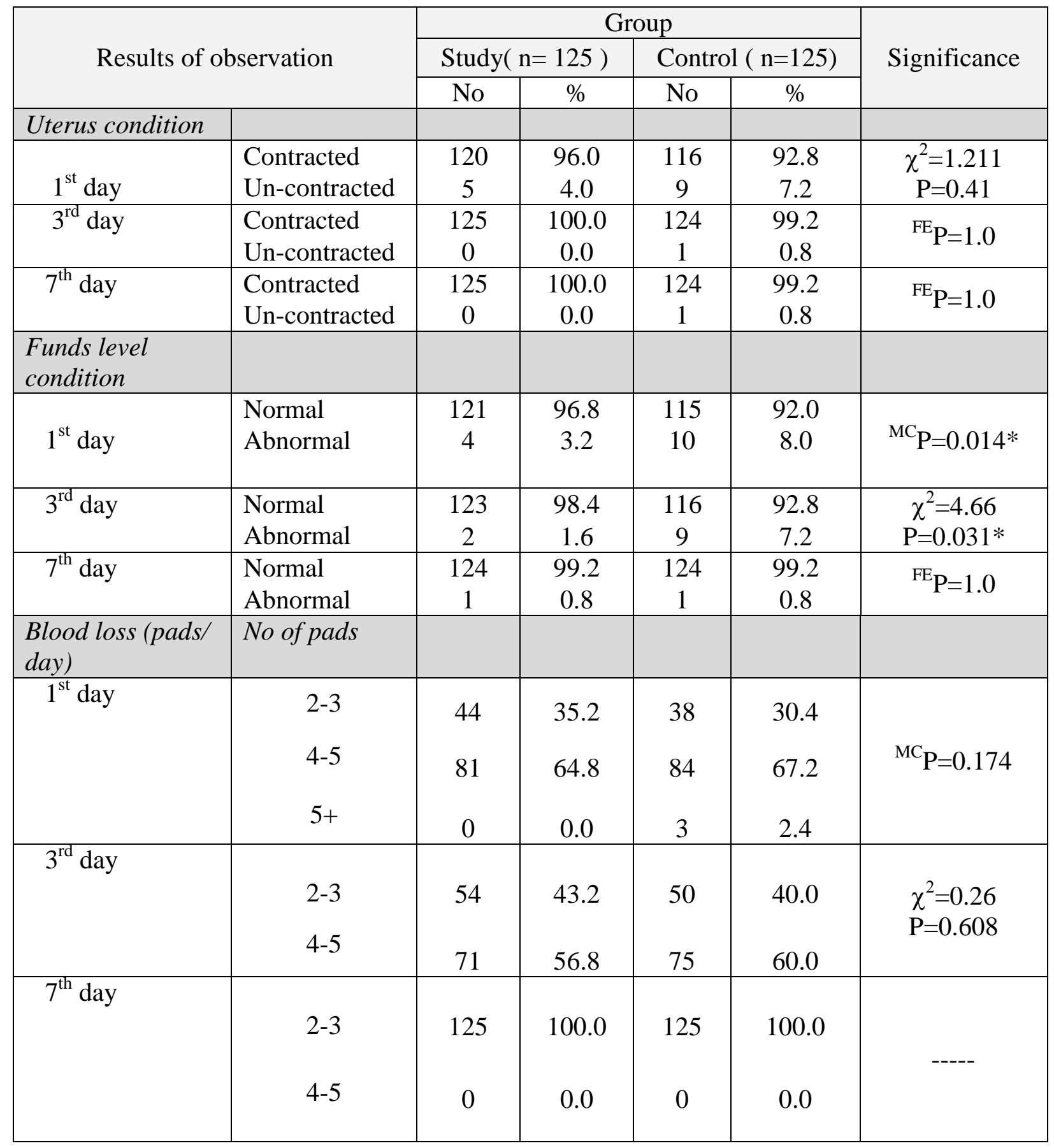


Table (4): Fluid intake and output among women in the study and control groups

\begin{tabular}{|c|c|c|c|c|c|c|}
\hline \multirow{3}{*}{\multicolumn{2}{|c|}{ Results of observation }} & \multicolumn{4}{|c|}{ Group } & \multirow{4}{*}{ Significance } \\
\hline & & \multicolumn{2}{|c|}{$\begin{array}{c}\text { Study } \\
(\mathrm{n}=125)\end{array}$} & \multicolumn{2}{|c|}{$\begin{array}{l}\text { Control } \\
(\mathrm{n}=125)\end{array}$} & \\
\hline & & No & $\%$ & No & $\%$ & \\
\hline \multicolumn{6}{|c|}{ Fluid intake } & \\
\hline \multirow[t]{2}{*}{$1^{\text {st }}$ day\# } & Oral & 106 & 84.8 & 7 & 5.6 & $\chi^{2}=158.3 \quad \mathrm{P}<0.0001 *$ \\
\hline & Parentral & 123 & 98.4 & 121 & 96.8 & ${ }^{\mathrm{FE}} \mathrm{P}=0.448$ \\
\hline \multirow[t]{2}{*}{$3^{\text {rd }}$ day\# } & Oral & 125 & 100.0 & 119 & 95.2 & ${ }^{\mathbf{F E}} \mathrm{P}=0.029^{*}$ \\
\hline & Parentral & 3 & 2.4 & 7 & 5.6 & $\chi^{2}=1.67 \mathrm{P}=0.197$ \\
\hline \multirow[t]{2}{*}{$7^{\text {th }}$ day\# } & Oral & 125 & 100.0 & 124 & 99.2 & ${ }^{\mathrm{FE}} \mathrm{P}=1.0$ \\
\hline & Parentral & 0 & 0.0 & 1 & 0.8 & \\
\hline \multicolumn{7}{|c|}{ \#Output fluids } \\
\hline \multirow[t]{2}{*}{$1^{\text {st }}$ day } & Urine & 122 & 97.6 & 122 & 97.6 & ${ }^{\mathrm{FE}} \mathrm{P}=1.0$ \\
\hline & Vomitus /others & 31 & 24.8 & 47 & 37.6 & $\chi^{2}=4.77 \mathrm{p}=0.029^{*}$ \\
\hline \multirow[t]{2}{*}{$3^{\text {rd }}$ day } & Urine & 124 & 99.2 & 124 & 99.2 & ${ }^{\mathrm{FE}} \mathrm{P}=1.0$ \\
\hline & Vomitus /others & 5 & 4.0 & 2 & 1.6 & ${ }^{\mathrm{FE}} \mathrm{P}=0.446$ \\
\hline \multirow[t]{2}{*}{$7^{\text {th }}$ day } & Urine & 121 & 96.8 & 119 & 95.2 & $\chi^{2}=0.417 \mathrm{p}=0.519$ \\
\hline & Vomitus /others & 2 & 1.6 & 0 & 0.0 & ${ }^{\mathrm{FE}} \mathrm{P}=0.498$ \\
\hline
\end{tabular}


Table (5): Wound status among women in the study and control groups

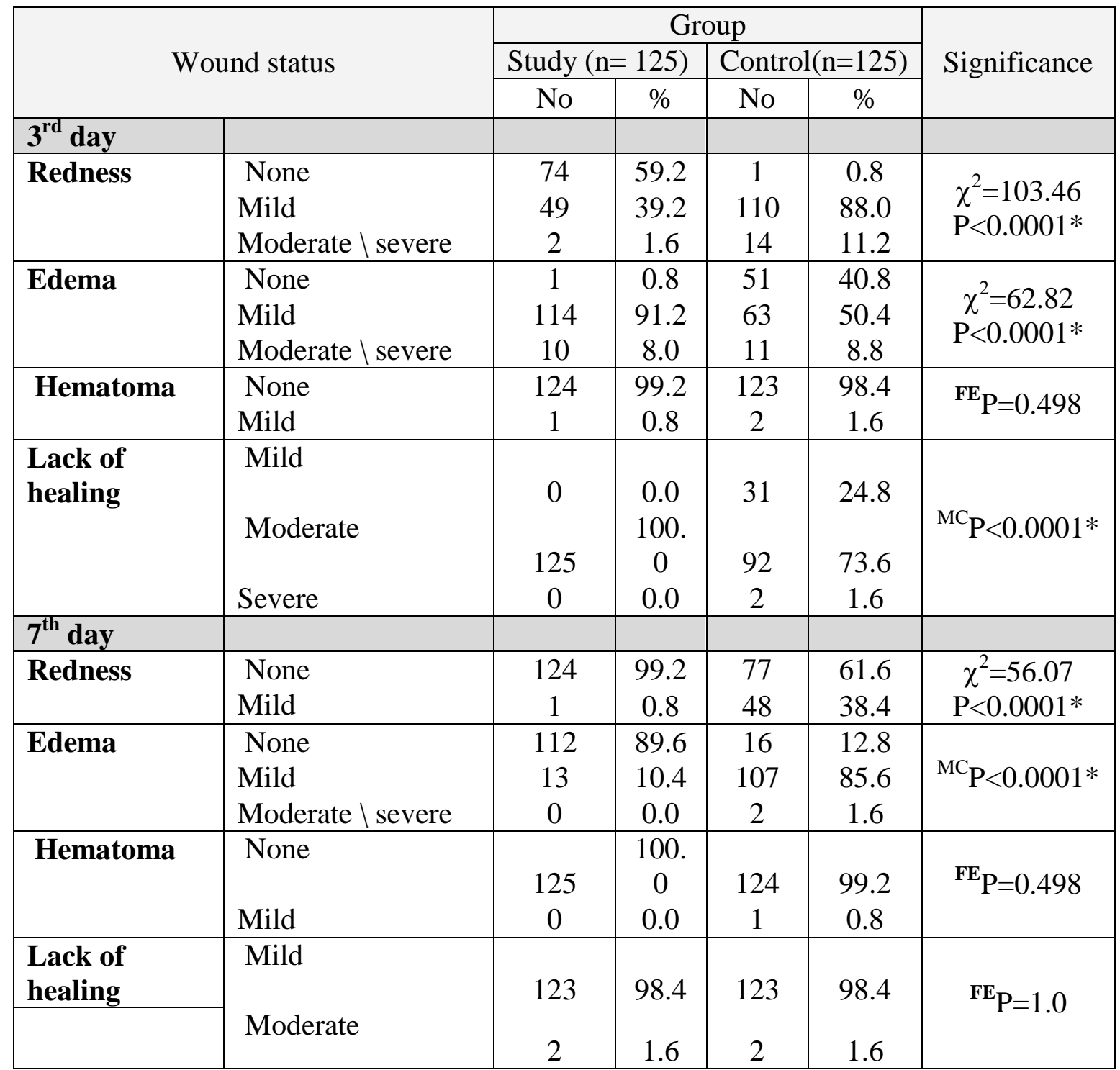

Table (6): Pain experienced by women in the study and control groups on the first, third, and seven days

\begin{tabular}{|l|c|c|c|c|c|}
\hline \multirow{2}{*}{$\begin{array}{l}\text { Level of } \\
\text { pain }\end{array}$} & \multicolumn{4}{|c|}{ Group } & \multirow{2}{*}{ Significance } \\
\cline { 2 - 5 } & \multicolumn{2}{|c|}{ Study ( $\mathrm{n}=125)$} & \multicolumn{2}{|c|}{ Control ( $\mathrm{n}=125)$} & \\
\hline $\mathbf{1}^{\text {st }}$ day & No & $\%$ & No & $\%$ & \\
Mild & 28 & 22.4 & 6 & 4.8 & $\chi^{2}=116.38$ \\
Moderate & 73 & 58.4 & 10 & 8.0 & $\mathrm{P}<0.0001^{*}$ \\
Severe & 24 & 19.2 & 109 & 87.2 & \\
\hline $\mathbf{3}^{\text {rd day }}$ & & & & & \\
Mild & 115 & 92.0 & 5 & 4.0 & $\chi^{2}=194.19$ \\
Moderate & 10 & 8.0 & 109 & 87.2 & $\mathrm{P}<0.0001^{*}$ \\
Severe & 0 & 0.0 & 11 & 8.8 & \\
\hline $\mathbf{7}^{\text {th day }}$ & & & & & \multirow{2}{*}{${ }^{\mathbf{F E}} \mathrm{P}=0.066$} \\
Mild & 124 & 99.2 & 118 & 94.4 & \\
Moderate & 1 & 0.8 & 7 & 5.6 & \\
\hline
\end{tabular}


Table (7): Post - cesarean complications among women in the study and control groups

\begin{tabular}{|c|c|c|c|c|c|}
\hline \multirow{3}{*}{ Complications } & \multicolumn{4}{|c|}{ Group } & \multirow{3}{*}{ Significance } \\
\hline & \multicolumn{2}{|c|}{$\begin{array}{c}\text { Study } \\
(\mathrm{n}=125)\end{array}$} & \multicolumn{2}{|c|}{$\begin{array}{l}\text { Control } \\
(\mathrm{n}=125)\end{array}$} & \\
\hline & No & $\%$ & No & $\%$ & \\
\hline \multicolumn{6}{|l|}{ At $1^{\text {st }}$ day\# } \\
\hline Retention of urine & 0 & 0.0 & 2 & 1.6 & ${ }^{\mathbf{F E}} \mathrm{P}=0.498$ \\
\hline Vaginal bleeding & 5 & 4.0 & 9 & 7.2 & $\begin{array}{c}\chi^{2}=1.211 \\
(0.271)\end{array}$ \\
\hline Wound bleeding & 0 & 0.0 & 2 & 1.6 & ${ }^{\mathbf{F E}_{\mathrm{P}}}=0.498$ \\
\hline Breast engorgement & 12 & 9.6 & 11 & 8.8 & $\begin{array}{l}\chi^{2}=0.048 \\
(0.827)\end{array}$ \\
\hline Abscess & 0 & 0.0 & 1 & 0.8 & ${ }^{\mathrm{FE}} \mathrm{P}=1.0$ \\
\hline Wound infection & 0 & 0.0 & 0 & 0.0 & ---- \\
\hline Puerperal sepsis & 0 & 0.0 & 1 & 0.8 & ${ }^{\mathbf{F E}} \mathrm{P}=1.0$ \\
\hline D.V.T & 0 & 0.0 & 0 & 0.0 & ---- \\
\hline Sub-involution & 0 & 0.0 & 2 & 1.6 & ${ }^{\mathrm{FE}} \mathrm{P}=0.498$ \\
\hline Pulmonary complications & 0 & 0.0 & 4 & 3.2 & ${ }^{\mathrm{FE}} \mathrm{P}=0.122$ \\
\hline $\begin{array}{l}\text { Abdominal distension and } \\
\text { Constipation }\end{array}$ & 41 & 32.8 & 92 & 73.6 & $\begin{array}{l}\chi^{2}=23.56 \\
(0.0001)^{*}\end{array}$ \\
\hline Hemorrhodis & 2 & 1.6 & 5 & 4.0 & ${ }^{\mathbf{F E}_{\mathrm{P}}=0.446}$ \\
\hline \multicolumn{6}{|l|}{ At $3^{\text {rd }}$ day\# } \\
\hline Retention of urine & 0 & 0.0 & 1 & 0.8 & ${ }^{\mathrm{FE}} \mathrm{P}=1.0$ \\
\hline Urinary tract infection & 0 & 0.0 & 1 & 0.8 & ${ }^{\mathrm{FE}} \mathrm{P}=1.0$ \\
\hline Vaginal bleeding & 0 & 0.0 & 0 & 0.0 & ---- \\
\hline Wound bleeding & 0 & 0.0 & 2 & 1.6 & ${ }^{\mathrm{FE}} \mathrm{P}=0.498$ \\
\hline Breast engorgement & 6 & 4.8 & 16 & 12.8 & $\begin{array}{l}\chi^{2}=4.98 \\
(0.026)^{*}\end{array}$ \\
\hline Abscess & 2 & 1.6 & 2 & 1.6 & ${ }^{\mathrm{FE}} \mathrm{P}=1.0$ \\
\hline Wound infection & 0 & 0.0 & 0 & 0.0 & ---- \\
\hline Puerperal sepsis & 0 & 0.0 & 0 & 0.0 & --- \\
\hline D.V.T & 0 & 0.0 & 6 & 4.8 & ${ }^{\mathrm{FE}} \mathrm{P}=0.029 *$ \\
\hline Subinvolution & 0 & 0.0 & 0 & 0.0 & ----- \\
\hline Pulmonary complications & 0 & 0.0 & 3 & 2.4 & ${ }^{\mathrm{FE}} \mathrm{P}=0.247$ \\
\hline $\begin{array}{l}\text { Abdominal distension and } \\
\text { Constipation }\end{array}$ & 28 & 22.4 & 59 & 47.2 & $\begin{array}{l}\chi^{2}=13.03 \\
(0.0001)^{*}\end{array}$ \\
\hline Hemorrhodis & 18 & 14.4 & 22 & 17.6 & $X^{2}=0.476 \quad(0.49)$ \\
\hline
\end{tabular}




\section{تأثثير إرشادات الرعاية التمريضية المقدمة للسيدات اللأتي أجريت لهن ولادة قيصرية علي حدوث مضاعفات بعد العملية القيصرية}

أ.د / شادية عبد القادر حسن ـ أ. د/ سونيه جمال الشرقاوي ـ أ.د / حمح عبد الحميد مطاوع - د/ نجاة

$$
\text { صلاح شلبي - م.م / مها رمضنان علي }
$$

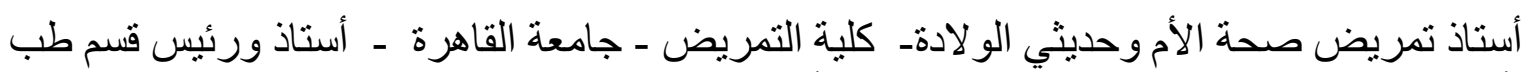

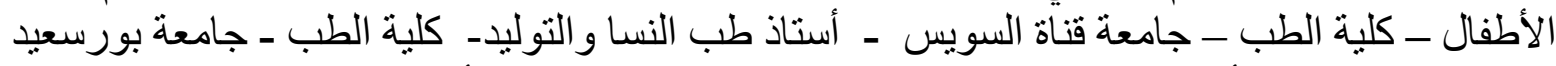

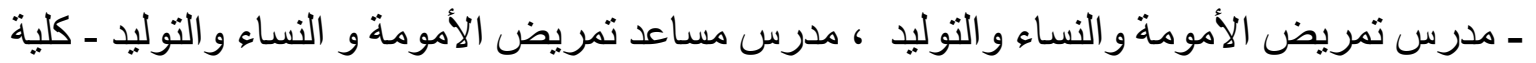
التمريض- جامعة بورسعيد

\section{الـخــلاصـــة}

الدر اسة الحالية در اسة شبة تجريبية هدفها تقييم تأثير إرشادات الر عاية التمريضية المقدمة للسيدات اللأتي أجريت لهن و لادة قيصرية وتقيم أثر هذه الرعاية التمريضية علي حدوث مضاعفات بعد العملية. وشملت عينة البحث (YO) سيدة .وقد تم تقسيم العينة إلي مجموعتين: المجموعة الأولي (المجموعة الضابطة) تشتمل علي (T T ( ) من السيدات تم إعطائهن الرعاية التمريضية من المستشفي و المجموعة الثانية

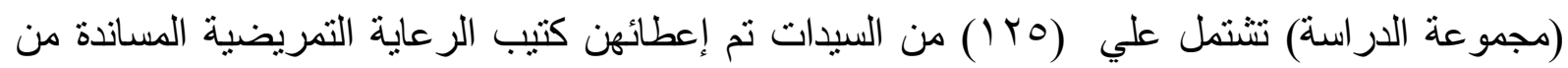
الباحثة. ـوقد تم تجميع البيانات عن طريق استخدام ثلاث استمارات استبيان ؛ الاستمارة الأولي استمارة استبيان للسيدات، ، الاستمارة الثانية استمارة للمتابعة وتتقسم إلى جزئيين تطبيق الرعاية التمريضية ، ملاحظة أداء السيدات، الاستمارة الثالثة استمارة ملاحظة تقييم المشاكل الصحية لدي السيدات بعد إجراء العملية مباثرة ثم بعد ثلاثة أيام ثم بعد أسبو عين .وتم تتفيذ برنامج الرعاية من خلال المقابلة الثخصية .وكان متوسط سن الأمهات ما بين · r- • ـ سنة . وقد أسفرت نتائج البحث علي أن البرنامج التدريبي أدي الي وجود فروق ذات دلالة إحصائية عن وجود تحسن واضح في معلومات ومهار ات الأمهات بالنسبة لبداية الرضاعة الطبيعية خلال الساعتين الأولي بعد الو لادة القيصرية وأيضا بالنسبة إلي الحركة المبكرة والنظافة الثخصية والتغذية واستخدام التمرينات و العناية بالجرح بعد الو لادة القيصرية لدي أمهات مجموعة الدر اسة . كما لوحظ أن معظم مضاعفات ما بعد الو لادة التي نت تسجيلها كانت في المجموعة الضابطة ـ بناءا علي نتائج الدراسة أوصي بأن تطبيق بر امج تعليمية باستخدام الوسائل المتاحة فيما يخص الرضاعة الطبيعية وصحة الأم في فترة ما بعد الو لادة القيصرية.

الكلمات الدالة : الولادة القيصرية -إرشادات الرعاية التمريضية - المضاعفات بعد العملية القيصرية القية 